\title{
Adoption patterns over time: a replication
}

\author{
Gil Appel ${ }^{1}$ (D) Eitan Muller $^{2}$ (D)
}

Accepted: 14 June 2021 / Published online: 20 September 2021

(c) The Author(s) 2021

\begin{abstract}
Based on new data, we replicate Mahajan et al.'s (1990) paper on adopter categories and Goldenberg et al.'s (2002) paper on saddles and offer explanations and extensions. We use a new dataset to replicate the results, namely, the U.S. Consumer Technology Association's Sales \& Forecasts, which provides longitudinal data on numerous consumer electronic products. Goldenberg, Libai, and Muller utilized the same source for 1999, while we use the updated 2021 report for the adopter category as well as the saddle replication, thus employing the same data source for both studies. We find that in the adoption of consumer electronics, there are fewer saddles, and these saddles are shorter and shallower in 2021 than they were in 1999. Regarding adopter categories, we break the data down by decades and show that, while the early adopter categories just barely decelerated over the six decades of our analysis, the average growth of the new dataset is much faster, with the peak occurring considerably sooner than that of the earlier data.
\end{abstract}

Keywords Acceleration · Adopter categories · Bass model · Innovation · New products $\cdot$ Peak time $\cdot$ Saddles

\section{Introduction}

Based on new data, we replicate Mahajan et al. (1990) (hereinafter: "MMS") on adopter categories and Goldenberg et al. (2002) ("GLM") on saddles and offer explanations and extensions. Adopter categories, namely, innovators, early adopters, early and late majority, and laggards, are the traditional segments for new products, used for targeting new customers, and for developing and retaining current ones (Rogers, 2003; Sood \& Kumar, 2017). This segmentation has been updated for

Eitan Muller

emuller@stern.nyu.edu

Gil Appel

gappel@gwu.edu

1 George Washington University, Washington, DC, USA

2 New York University and The Interdisciplinary Center (IDC), New York, NY, USA 
technology innovations to a dual market structure - early and main markets - that are in some cases separated by a temporal slump in sales, or a saddle. The main difference between these two segments is based on the benefits that consumers gain from the product; see also Golder and Tellis (2004), Hauser et al. (2006), Van den Bulte and Joshi (2007), Chandrasekaran and Tellis (2011), and Chu et al. (2017). While previous studies have chronicled the relative sizes of the categories, as well as the prevalence of saddles, on datasets that were available at the time, we use a new dataset to replicate the results and discuss the differences.

We observe that not only has the average depth of saddles decreased, their average duration has considerably shrunk from almost 4 years to slightly more than 2 years. Moreover, their occurrence dropped considerably from $50 \%$ to less than $30 \%$. Thus, in the adoption of consumer electronics, there are fewer saddles, and these saddles are shorter and shallower in 2021 than they were in 1999.

Regarding adopter categories, we break the data down by decades, as doing so yields a more accurate picture of the results, and shows that while the early adopter categories just barely decelerated over the six decades of our analysis, the average growth of the new dataset is faster, with peak occurring considerably sooner than that of the earlier data.

\section{Data}

We use U.S. Consumer Technology Sales \& Forecasts, a biannual report published by the Consumer Technology Association (CTA, formerly CEA) that provides longitudinal data on numerous consumer electronic products. While GLM utilized this source for 1999, we use the updated 2021 report for both the adopter category and the saddle replication, thus using the same data for both studies. As did GLM, we used products with at least 8 datapoints and removed products that were mere groupings of other product categories (e.g., wireless phone accessories); did not have unit sales data (i.e., had dollar sales or penetration rates); were a subset of a product (e.g., wireless around-the-ear headphones versus "wireless headphones"); or for which the data was provided late in the life cycle of the product, such that the time series was already showing a rapid decline. GLM used products with at least 8 datapoints and had data up to 1998; thus, these products began selling in the USA prior to 1991. We thus use this year (1991) as the cutoff point for our products, hence including all products with at least 8 datapoints that began selling in the USA in or after 1992, thereby ensuring that no product appears in both datasets. We denote these datasets as the 1999 and 2021 datasets respectively, while for the adopter categories, we break the data down by decades as doing so yields a more accurate picture of the results.

The GLM (1999) dataset contained 32 products, while the new dataset (2021) contains 48 products. We also included in the data six products that had 7 datapoints, which we refer to as the extended dataset: While we do not consider these products in the saddle analysis, as they are too short a series to examine, and we wish to precisely replicate GLM that had a minimum of 8 points, we do consider these products when we explored the change in the diffusion coefficients in Section 4. The full list of products and their attributes is in Appendix A Table 5. 
Table 1 Prevalence of saddles, by dataset

\begin{tabular}{llllll}
\hline Datasets & $\begin{array}{l}\text { Number of new } \\
\text { products }\end{array}$ & $\begin{array}{l}\text { Products with } \\
\text { saddle }\end{array}$ & $\%$ with saddle & Ave. depth (\%) & $\begin{array}{l}\text { Ave. } \\
\text { duration } \\
\text { (years) }\end{array}$ \\
\hline New (2021) & 48 & 14 & $29 \%$ & $22 \%$ & 2.4 \\
GLM (1999) & 32 & 16 & $50 \%$ & $25 \%$ & 3.9 \\
\hline
\end{tabular}

\section{The decline in prevalence of saddles}

Early and main market adopter segments develop differently over time: If the early market diffuses earlier and faster than the main market, and there is a partial break in social contagion between the two segments, a saddle, that is a temporary decline in the sales of the product, ensues. This saddle will wither over time, as the adoption of the main market speeds up. Note that this is a more general definition than the one found in GLM as it does not require the two segments to be related to their appreciation and knowledge of high technology. Any two segments that consistently differ in their speed of adoption might create a saddle.

To identify saddles in the 2021 dataset, we use the exact same specification of GLM, of a saddle that has either a minimum duration of 1 year with minimum depth of $10 \%$, or else a minimum duration of 2 years with no minimum depth ${ }^{1}$. Table 1 lists the summary statistics of both datasets, Table 2 lists the saddles found in the new data, and Figure 1 depicts two saddles from the new data (GLM presented examples of saddles from their own data).

What we observe from the tables is that while the average depth of saddles has somewhat decreased, their average duration has considerably shrunk from almost 4 years to slightly over 2 years. Moreover, the occurrence of saddles dropped considerably from $50 \%$ to less than $30 \%$. We can conclude that in the adoption of consumer electronics, over the course of 20 years, there are fewer saddles, and those saddles are shorter and shallower.

There are three main reasons why we find fewer saddles in the newer dataset: First, GLM showed that the main reason for the saddle is a (partial) break in communication between the early and main markets (see Chandrasekaran \& Tellis, 2011 for an in-depth review of the phenomenon). However, in more recent times, the flood of information with respect to new products and their attributes that newer markets exhibit renders the lack of information transmission between early and late market less impactful. Many of these new products, such as smartphones and streaming media players, are in themselves agents of such communication, bringing accessible innovation to multitudes of consumers.

Second, firms are taking the possibility of a saddle into account and are working to mitigate its effect (Goldenberg et al., 2006), and thus what we see is a resultant

\footnotetext{
1 This is the "relaxed" version of the definition in GLM Table 1, though the wording in the text is somewhat imprecise. The exact definition is the one given here: A minimum duration of one year with depth of at least $10 \%$; or else a minimum duration of 2 years.
} 
Table 2 Saddle properties of the 2021 dataset

\begin{tabular}{llll}
\hline Saddle start year & Innovation with saddle & Relative depth (\%) & $\begin{array}{l}\text { Dura- } \\
\text { tion } \\
\text { (years) }\end{array}$ \\
\hline 1997 & Home theater-in-a-box ${ }^{*}$ & $20 \%$ & 2 \\
2003 & Standard DVD players & $15 \%$ & 2 \\
2007 & Wireless headphones ${ }^{*}$ & $27 \%$ & 5 \\
2008 & OLED TV & 4 \\
2009 & Cable set-top boxes & $89 \%$ & 2 \\
2009 & Laptop/notebook PCs & $8 \%$ & 3 \\
2010 & Home robots & $10 \%$ & 2 \\
2010 & Wired earbuds ${ }^{*}$ & $8 \%$ & 3 \\
2012 & Digital video recorders (DVRs) & $22 \%$ & 2 \\
2012 & Wired headphones & $18 \%$ & 1 \\
2015 & Smartwatches & $21 \%$ & 1 \\
2017 & Desktop 3D printers & $15 \%$ & 3 \\
2017 & Digital TV sets and displays & $18 \%$ & 2 \\
2017 & Smart TVs & $11 \%$ & 1 \\
\hline
\end{tabular}

*With GLM's strict definition of at least 2 years and $20 \%$ depth, the new dataset has 4 saddles vs 11 of GLM

market structure that follows these actions, namely, with a lower likelihood of a saddle. Research has proposed that "seeding" the market with free samples can help mitigate the saddle effect (Lehmann \& Esteban-Bravo, 2006) and it has become far easier for companies to run free sampling and seeding campaigns, as they can release those in digital form ( $\mathrm{Li}$ et al., 2019).

Third, the advent of the internet and subsequently social media has made information sharing faster and accessible from virtually any location. We observe two concurrent effects here, as the internet enabled faster diffusion of any message, providing an infrastructure for digital advertising and social media platforms, thereby enabling the internal and external coefficients to increase over time, as can be seen

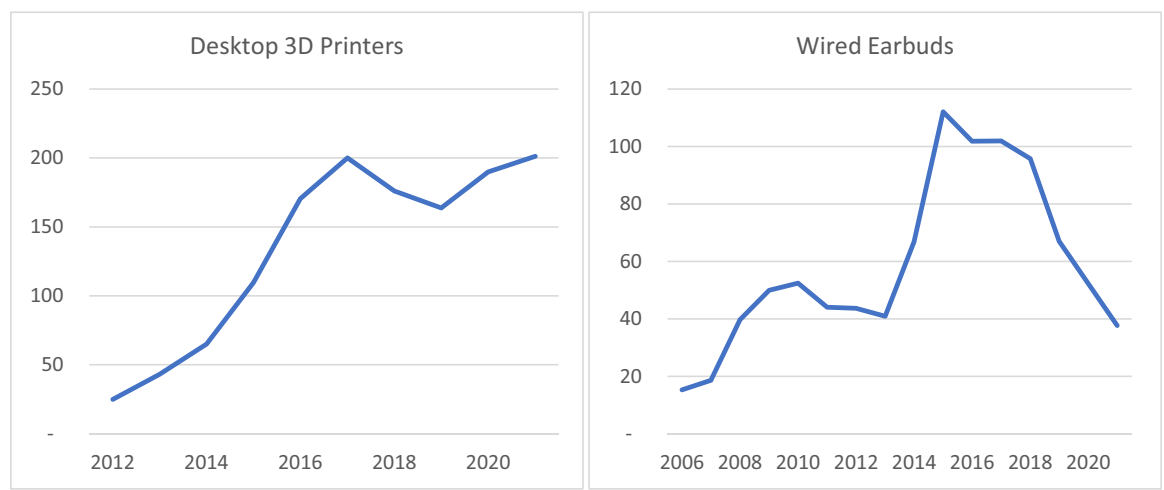

Figure 1 Saddle in desktop 3D printers and wired earbuds (new data) (desktop 3D printers and wired earbuds are in thousands and millions of units respectively; 2021 figures are estimates) 
in Table 3. Social media platforms, on the other hand, enabled consumers to communicate better, pushing the internal coefficient to higher levels over time. Considering new innovation, from virtual influencers to augmented reality, we can safely predict that social media will only increase in importance and in turn increase our ability to communicate and influence others over time (Appel et al., 2020).

One important thing to note is that increase in social communication as a process preceded the advent of social media, or even the internet. Looking at the scatter plots of the internal coefficient in Figure 3 of Appendix B, it seems that the internal coefficient began accelerating in the 1960s, long before the advent of social media or the internet (and similarly for the external coefficient). From the plots, it seems that the variance of the coefficients increased with the introduction of the internet and social media.

\section{The acceleration of adoption curves}

Next, we estimated the diffusion coefficients for the products in both datasets using the NLS method (Srinivasan \& Mason, 1986). One benefit of this method is that it enables us to use the actual launch year (i.e., the year the product was first introduced to the market) rather than the data start year (i.e., the year data on the product was first available in the CEA dataset) in our estimations. We used historical analysis (Golder \& Tellis, 1993) to identify the launch year for the products in both datasets. This method provided a more accurate analysis, and more stable estimations yielding higher $R^{2}$ values.

Adopter categories is the traditional segmentation method for new products, defined by the inflection points and the peak time of the Bass diffusion model (Rogers, 2003, MMS 1990). As shown in Appendix A Table 5, the individual Bass model regressions work well on the data, yielding an average $R$-Square of $86 \%$. While these data are summarized in Table 3, Table 4 shows the developing nature of the adopter categories over the decades of our data.

It appears from the categories that products are being adopted later in the product life cycle, as the number of innovators and early adopters has slowly dropped decade by decade. This drop is absorbed almost equally by the other three categories, slightly increasing the latter's sizes over time (using the equations of the product

Table 3 Per period average diffusion parameters and peak times

\begin{tabular}{llllll}
\hline Period & \# of products & $\begin{array}{l}\text { External } \\
\text { coefficient } \\
(p)\end{array}$ & $\begin{array}{l}\text { Internal } \\
\text { coefficient } \\
(q)\end{array}$ & Peak time & $\mathrm{p} / \mathrm{q}$ \\
\hline Pre-1970 & 12 & 0.001 & 0.18 & 51 & 0.005 \\
$1970-1979$ & 12 & 0.002 & 0.27 & 27 & 0.008 \\
$1980-1989$ & 18 & 0.007 & 0.31 & 22 & 0.022 \\
$1990-1999$ & 20 & 0.013 & 0.48 & 14 & 0.027 \\
$2000-2009$ & 15 & 0.019 & 0.44 & 13 & 0.043 \\
Post-2010 & 9 & 0.024 & 0.48 & 10 & 0.049 \\
\hline
\end{tabular}


Table 4 Adopter categories by decades

\begin{tabular}{llllll}
\hline Period & \# of products & $\begin{array}{l}\text { Innovators } \\
+ \text { early } \\
\text { adopters }\end{array}$ & $\begin{array}{l}\text { Early major- } \\
\text { ity }\end{array}$ & Late majority & Laggards \\
\hline Pre-1970 & 12 & $20.7 \%$ & $29.0 \%$ & $29.0 \%$ & $21.2 \%$ \\
$1970-1979$ & 12 & $20.5 \%$ & $29.1 \%$ & $29.1 \%$ & $21.3 \%$ \\
$1980-1989$ & 18 & $19.4 \%$ & $29.5 \%$ & $29.5 \%$ & $21.6 \%$ \\
$1990-1999$ & 20 & $19.0 \%$ & $29.6 \%$ & $29.6 \%$ & $21.7 \%$ \\
$2000-2009$ & 15 & $17.8 \%$ & $30.1 \%$ & $30.1 \%$ & $22.0 \%$ \\
Post-2010 & 9 & $17.3 \%$ & $30.3 \%$ & $30.3 \%$ & $22.2 \%$ \\
\hline
\end{tabular}

categories in MMS, it is straightforward to prove that this is entirely explained by the increase in the ratio of $p / q$ as shown in Table 3). Interestingly, adopter categories only give a partial picture of the product life cycle, as the more remarkable nature of the data's change over time lies in the recent left skewness of the data. To demonstrate, observe Figure 2 that shows the new product diffusion curves, averaged over the two main datasets (1999 and 2021).

Though, as we showed, the adopter categories seem to shift slowly to later adoption over time, the adoption curves themselves changed. The new adoption curve is faster, with peak occurring much sooner than that of the earlier data. In fact, the time it takes to be considered a Laggard now would label the same consumer as early market (if not earlier) in earlier times.

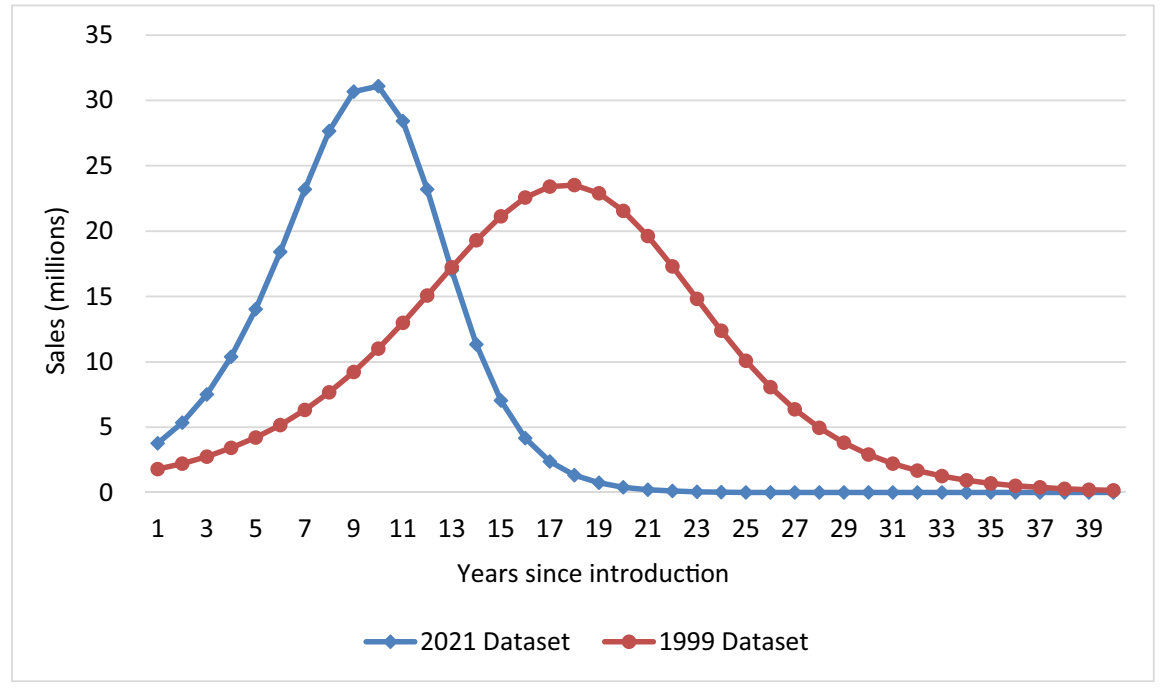

Figure 2 Average new product diffusion by dataset (the market potential of the 2021 dataset is actually smaller than that of the 1999 dataset ( $269 \mathrm{~m}$ vs $363 \mathrm{~m}$, on average). The 2021 sales curve reaches this smaller potential much faster) 
While the figure demonstrates the left skewness effect for the two datasets, Table 3 shows that this is a consistent phenomenon: Time to peak has gotten considerably shorter over the last decades, and the diffusion coefficients are getting larger, both monotonically over time.

\section{Managerial implications}

In this paper, we find that in the adoption of consumer electronics, there are fewer saddles and these saddles have become shorter and shallower in 2021. We also show that, while most adopter categories barely changed over the six decades of our analysis, the average growth in the new dataset is faster, with peak occurring sooner than that of the earlier data. Yet this is not limited to electronic goods, as other recent innovations have also demonstrated an accelerated growth pace. A notable example is the explosion of the various "sharing economy" platforms such as Uber, Airbnb, or Postmates, allowing people to share their cars, home, or free time with others for a fee (Muller, 2020; Zervas et al., 2017). These platforms have grown at a pace never before seen in other products. For example, the first ever Uber ride was requested on July 5, 2010, and it took Uber just over 5 years to reach their billionth ride (Mclean, 2015). For comparison, even McDonald's needed more than 8 years to sell a billion burgers (Wilson, 2013), a product cheaper and more accessible than an Uber ride.

Likewise, in the 2021 data, we observe products that in a few short years have become commonplace, such as home robots, tablet PCs, and Bluetooth speakers. Interestingly, more complex technological advances, such as smartwatches and smart TVs, still exhibit a saddle. Perhaps the complexity of these products deters the early market from adopting earlier.

The left skewness of the newer data is a market structure that follows decisions of firms that market new innovations, where marketing managers are not limited to traditional digital marketing methods such as advertising on social media platforms and websites. These marketers have introduced new and disruptive marketing methods that have been termed "growth hacking": The term describes a collection of disruptive growth strategies that relies on any mechanism, including hacking, that will spur growth via usage of social media and increased social contagion. Arguably, the best example of this strategy is the "integration" of Craigslist into Airbnb in its early days, where a potential user who clicked on an Airbnb listing in Craigslist would be transferred to Airbnb's website, thus enabling the latter to tap into the massive user base of the former (see growthhackers. com/growth-studies). The result of such strategies, both traditional and disruptive, is left skewness of the diffusion curves, as demonstrated in the paper. 


\section{Appendix}

Table 5 Diffusion parameters and peak time of innovations, by data start year

\begin{tabular}{|c|c|c|c|c|c|c|c|c|}
\hline Product & $\begin{array}{l}\text { Data Start } \\
\text { Year }\end{array}$ & $\begin{array}{l}\text { Launch } \\
\text { Year }\end{array}$ & Dataset & $p$ & $q$ & $N$ (million) & $T^{*}$ & $\mathrm{R}^{2}$ \\
\hline Monochrome TV & 1946 & 1939 & GLM (1999) & 0.0077 & 0.09 & 275 & 27 & $67 \%$ \\
\hline Home Radios & 1950 & 1920 & GLM (1999) & 0.0004 & 0.10 & 1,392 & 57 & $76 \%$ \\
\hline Color TV & 1954 & 1954 & GLM (1999) & 0.0014 & 0.11 & 783 & 41 & $97 \%$ \\
\hline VCR Decks & 1974 & 1972 & GLM (1999) & 0.0031 & 0.17 & 359 & 25 & $87 \%$ \\
\hline $\begin{array}{l}\text { Aftermarket PC } \\
\text { Monitors }\end{array}$ & 1980 & 1960 & GLM (1999) & 0.0002 & 0.11 & 336 & 57 & $92 \%$ \\
\hline $\begin{array}{l}\text { Compact Audio } \\
\text { Systems }\end{array}$ & 1980 & 1960 & GLM (1999) & 0.0003 & 0.11 & 732 & 58 & $80 \%$ \\
\hline Cordless Phones & 1980 & 1977 & GLM (1999) & 0.0008 & 0.16 & 2,183 & 35 & $98 \%$ \\
\hline PC Printers & 1980 & 1970 & GLM (1999) & 0.0001 & 0.19 & 770 & 41 & $93 \%$ \\
\hline $\begin{array}{l}\text { Personal Com- } \\
\text { puters }\end{array}$ & 1980 & 1974 & GLM (1999) & 0.0006 & 0.15 & 944 & 40 & $93 \%$ \\
\hline $\begin{array}{l}\text { Rack Audio } \\
\text { Systems }\end{array}$ & 1980 & 1958 & GLM (1999) & 0.0001 & 0.30 & 24 & 31 & $64 \%$ \\
\hline $\begin{array}{l}\text { Blank Videocas- } \\
\text { settes }\end{array}$ & 1982 & 1976 & GLM (1999) & 0.0066 & 0.19 & 8 & 19 & $87 \%$ \\
\hline Corded Phones & 1982 & 1930 & GLM (1999) & 0.0001 & 0.09 & 1,257 & 73 & $63 \%$ \\
\hline $\begin{array}{l}\text { Personal Word } \\
\text { Processors }\end{array}$ & 1982 & 1982 & GLM (1999) & 0.0334 & 0.20 & 48 & 9 & $81 \%$ \\
\hline $\begin{array}{l}\text { Telephone } \\
\text { Answering } \\
\text { Devices }\end{array}$ & 1982 & 1960 & GLM (1999) & 0.0001 & 0.24 & 308 & 36 & $96 \%$ \\
\hline $\begin{array}{l}\text { LCD Mono- } \\
\text { chrome TV }\end{array}$ & 1983 & 1982 & GLM (1999) & 0.0278 & 0.19 & 10 & 10 & $58 \%$ \\
\hline $\begin{array}{l}\text { Portable Tape } \\
\text { Players }\end{array}$ & 1983 & 1975 & GLM (1999) & 0.0053 & 0.24 & 285 & 18 & $90 \%$ \\
\hline Total CD Players & 1983 & 1982 & GLM (1999) & 0.0030 & 0.35 & 427 & 16 & $98 \%$ \\
\hline Cellular Phones & 1984 & 1983 & GLM (1999) & 0.0018 & 0.48 & 111 & 15 & $99 \%$ \\
\hline $\begin{array}{l}\text { Color TV with } \\
\text { Stereo }\end{array}$ & 1984 & 1984 & GLM (1999) & 0.0097 & 0.17 & 319 & 18 & $95 \%$ \\
\hline $\begin{array}{l}\text { Modems / Fax } \\
\text { Modems }\end{array}$ & 1984 & 1962 & GLM (1999) & 0.0000 & 0.48 & 80 & 37 & $100 \%$ \\
\hline $\begin{array}{c}\text { Blank Audio } \\
\text { Cassettes }\end{array}$ & 1985 & 1964 & GLM (1999) & 0.0014 & 0.18 & 10 & 29 & $87 \%$ \\
\hline Camcorders & 1985 & 1973 & GLM (1999) & 0.0023 & 0.21 & 68 & 24 & $92 \%$ \\
\hline Laserdisc Player & 1985 & 1978 & GLM (1999) & 0.0010 & 0.53 & 2 & 15 & $90 \%$ \\
\hline LCD Color TV & 1985 & 1984 & GLM (1999) & 0.0161 & 0.26 & 5 & 12 & $94 \%$ \\
\hline Projection TV & 1985 & 1978 & GLM (1999) & 0.0009 & 0.16 & 76 & 36 & $95 \%$ \\
\hline $\begin{array}{l}\text { Videocassette } \\
\text { Players }\end{array}$ & 1985 & 1977 & GLM (1999) & 0.0046 & 0.30 & 6 & 16 & $76 \%$ \\
\hline DBS Satellite & 1986 & 1975 & GLM (1999) & 0.0000 & 0.67 & 17 & 22 & $92 \%$ \\
\hline $\begin{array}{l}\text { VCR Decks with } \\
\text { Stereo }\end{array}$ & 1986 & 1982 & GLM (1999) & 0.0009 & 0.23 & 484 & 27 & $98 \%$ \\
\hline
\end{tabular}


Table 5 (continued)

\begin{tabular}{|c|c|c|c|c|c|c|c|c|}
\hline Product & $\begin{array}{l}\text { Data Start } \\
\text { Year }\end{array}$ & $\begin{array}{l}\text { Launch } \\
\text { Year }\end{array}$ & Dataset & $p$ & $q$ & $N$ (million) & $T^{*}$ & $\mathrm{R}^{2}$ \\
\hline $\begin{array}{l}\text { Blank Floppy } \\
\text { Diskettes }\end{array}$ & 1987 & 1981 & GLM (1999) & 0.0121 & 0.23 & 10 & 14 & $96 \%$ \\
\hline Fax Machines & 1987 & 1980 & GLM (1999) & 0.0032 & 0.32 & 37 & 17 & $92 \%$ \\
\hline $\begin{array}{l}\text { Portable CD } \\
\text { Equipment }\end{array}$ & 1987 & 1984 & GLM (1999) & 0.0040 & 0.41 & 211 & 14 & $96 \%$ \\
\hline $\begin{array}{l}\text { TV/VCR Combi- } \\
\text { nations }\end{array}$ & 1990 & 1986 & GLM (1999) & 0.0085 & 0.34 & 32 & 13 & $91 \%$ \\
\hline $\begin{array}{l}\text { Aftermarket } \\
\text { Remote Con- } \\
\text { trols }\end{array}$ & 1991 & 1985 & New (2021) & 0.0043 & 0.25 & 494 & 19 & $95 \%$ \\
\hline Digital Cameras & 1996 & 1990 & New (2021) & 0.0008 & 0.40 & 373 & 19 & $95 \%$ \\
\hline $\begin{array}{l}\text { Home Theater- } \\
\text { in-a-Box }\end{array}$ & 1996 & 1994 & New (2021) & 0.0110 & 0.31 & 48 & 12 & $94 \%$ \\
\hline $\begin{array}{l}\text { Caller ID } \\
\text { Devices }\end{array}$ & 1996 & 1991 & New (2021) & 0.0281 & 0.42 & 48 & 8 & $95 \%$ \\
\hline $\begin{array}{l}\text { Family Radio } \\
\text { Devices }\end{array}$ & 1997 & 1996 & New (2021) & 0.0316 & 0.23 & 162 & 9 & $57 \%$ \\
\hline $\begin{array}{l}\text { Set-Top Internet } \\
\text { Devices }\end{array}$ & 1997 & 1996 & New (2021) & 0.0831 & 0.61 & 7 & 4 & $96 \%$ \\
\hline $\begin{array}{l}\text { Standard DVD } \\
\text { Players }\end{array}$ & 1997 & 1997 & New (2021) & 0.0223 & 0.27 & 283 & 10 & $90 \%$ \\
\hline $\begin{array}{l}\text { Digital TV Sets } \\
\text { and Displays }\end{array}$ & 1998 & 1998 & New (2021) & 0.0068 & 0.19 & 869 & 19 & $91 \%$ \\
\hline $\begin{array}{l}\text { Digital Projection } \\
\text { TV }\end{array}$ & 1999 & 1998 & New (2021) & 0.0233 & 0.66 & 19 & 7 & $97 \%$ \\
\hline $\begin{array}{l}\text { Plasma Flat Panel } \\
\text { TV }\end{array}$ & 1999 & 1997 & New (2021) & 0.0032 & 0.51 & 33 & 13 & $95 \%$ \\
\hline $\begin{array}{l}\text { Portable Media } \\
\text { Players }\end{array}$ & 1999 & 1998 & New (2021) & 0.0076 & 0.46 & 384 & 11 & $89 \%$ \\
\hline $\begin{array}{l}\text { Digital Direct- } \\
\text { View TV }\end{array}$ & 2000 & 1998 & New (2021) & 0.0027 & 1.16 & 12 & 8 & $78 \%$ \\
\hline $\begin{array}{l}\text { Personal Digital } \\
\text { Assistants }\end{array}$ & 2000 & 1993 & New (2021) & 0.0260 & 0.33 & 68 & 9 & $99 \%$ \\
\hline $\begin{array}{l}\text { Portable Naviga- } \\
\text { tion Devices }\end{array}$ & 2000 & 1989 & New (2021) & 0.0001 & 0.47 & 118 & 21 & $75 \%$ \\
\hline Front Projection & 2002 & 1973 & New (2021) & 0.0003 & 0.20 & 23 & 36 & $87 \%$ \\
\hline $\begin{array}{l}\text { Cable Set-Top } \\
\text { Boxes }\end{array}$ & 2003 & 1950 & New (2021) & 0.0000 & 0.15 & 412 & 64 & $82 \%$ \\
\hline $\begin{array}{l}\text { Digital Video } \\
\text { Recorders }\end{array}$ & 2003 & 1999 & New (2021) & 0.0082 & 0.34 & 209 & 13 & $75 \%$ \\
\hline $\begin{array}{l}\text { Laptop/Notebook } \\
\text { PCs }\end{array}$ & 2003 & 1983 & New (2021) & 0.0003 & 0.16 & 1,802 & 42 & $96 \%$ \\
\hline Smartphones & 2003 & 1995 & New (2021) & 0.0008 & 0.31 & 2,371 & 22 & $96 \%$ \\
\hline VoIP Adapters & 2003 & 2003 & New (2021) & 0.0490 & 0.53 & 58 & 6 & $92 \%$ \\
\hline IPTV & 2004 & 2004 & New (2021) & 0.0220 & 0.28 & 56 & 10 & $82 \%$ \\
\hline
\end{tabular}


Table 5 (continued)

\begin{tabular}{|c|c|c|c|c|c|c|c|c|}
\hline Product & $\begin{array}{l}\text { Data Start } \\
\text { Year }\end{array}$ & $\begin{array}{l}\text { Launch } \\
\text { Year }\end{array}$ & Dataset & $p$ & $q$ & $N$ (million) & $T^{*}$ & $\mathrm{R}^{2}$ \\
\hline $\begin{array}{l}\text { Streaming Media } \\
\text { Players }\end{array}$ & 2004 & 2002 & New (2021) & 0.0026 & 0.31 & 279 & 18 & $98 \%$ \\
\hline $\begin{array}{l}\text { Digital-to-Analog } \\
\text { Converters }\end{array}$ & 2005 & 2005 & New (2021) & 0.0857 & 1.47 & 57 & 4 & $74 \%$ \\
\hline Blu-ray Players & 2006 & 2006 & New (2021) & 0.0395 & 0.38 & 92 & 7 & $90 \%$ \\
\hline $\begin{array}{l}\text { Digital Photo } \\
\text { Frames }\end{array}$ & 2006 & 1999 & New (2021) & 0.0051 & 0.53 & 67 & 11 & $90 \%$ \\
\hline E-readers & 2006 & 2004 & New (2021) & 0.0196 & 0.37 & 104 & 9 & $39 \%$ \\
\hline $\begin{array}{l}\text { Full HDTV } \\
\text { (1080p) }\end{array}$ & 2006 & 2005 & New (2021) & 0.0198 & 0.37 & 252 & 9 & $91 \%$ \\
\hline Wired Earbuds & 2006 & 1984 & New (2021) & 0.0000 & 0.37 & 1,039 & 32 & $76 \%$ \\
\hline $\begin{array}{l}\text { Wired Head- } \\
\text { phones }\end{array}$ & 2006 & 1910 & New (2021) & 0.0000 & 0.19 & 499 & 103 & $72 \%$ \\
\hline $\begin{array}{l}\text { Wireless Head- } \\
\text { phones }\end{array}$ & 2006 & 1999 & New (2021) & 0.0000 & 0.62 & 74 & 21 & $98 \%$ \\
\hline OLED TV & 2008 & 2008 & New (2021) & 0.0011 & 0.62 & 23 & 14 & $98 \%$ \\
\hline Soundbars & 2008 & 1998 & New (2021) & 0.0003 & 0.39 & 105 & 22 & $97 \%$ \\
\hline $\begin{array}{l}\text { Health and Fit- } \\
\text { ness Technol- } \\
\text { ogy }\end{array}$ & 2009 & 1981 & New (2021) & 0.0000 & 0.38 & 310 & 38 & $85 \%$ \\
\hline $\begin{array}{l}\text { Portable Wireless } \\
\text { Speakers }\end{array}$ & 2009 & 1999 & New (2021) & 0.0000 & 0.69 & 388 & 21 & $98 \%$ \\
\hline Smart TVs & 2009 & 2008 & New (2021) & 0.0094 & 0.34 & 434 & 12 & $94 \%$ \\
\hline Tablet PCs & 2009 & 2002 & New (2021) & 0.0055 & 0.37 & 713 & 14 & $61 \%$ \\
\hline Home Robots & 2010 & 1982 & New (2021) & 0.0000 & 0.52 & 35 & 39 & $98 \%$ \\
\hline 4K Ultra HDTVs & 2012 & 2012 & New (2021) & 0.0109 & 0.58 & 222 & 9 & $97 \%$ \\
\hline $\begin{array}{l}\text { Action Camcord- } \\
\text { ers }\end{array}$ & 2012 & 2004 & New (2021) & 0.0052 & 0.36 & 28 & 14 & $78 \%$ \\
\hline $\begin{array}{c}\text { Desktop 3D } \\
\text { Printers }\end{array}$ & 2012 & 2001 & New (2021) & 0.0008 & 0.41 & 2 & 18 & $86 \%$ \\
\hline Smartwatches & 2012 & 1999 & New (2021) & 0.0001 & 0.55 & 171 & 21 & $95 \%$ \\
\hline $\begin{array}{l}\text { Connected Ther- } \\
\text { mostats }\end{array}$ & 2013 & 2008 & New (2021) & 0.0150 & 0.30 & 27 & 11 & $38 \%$ \\
\hline Drones & 2013 & 2010 & New (2021) & 0.0100 & 0.52 & 29 & 10 & $91 \%$ \\
\hline $\begin{array}{l}\text { Fitness Activity } \\
\text { Trackers }\end{array}$ & 2013 & 1981 & New (2021) & 0.0000 & 0.33 & 246 & 37 & $37 \%$ \\
\hline $\begin{array}{l}\text { IP/Wi-Fi Cam- } \\
\text { eras }\end{array}$ & 2013 & 1999 & New (2021) & 0.0000 & 0.65 & 73 & 21 & $97 \%$ \\
\hline $\begin{array}{r}\text { Rear View } \\
\text { Cameras }\end{array}$ & 2013 & 2002 & New (2021) & 0.0015 & 0.31 & 16 & 20 & $98 \%$ \\
\hline $\begin{array}{l}\text { Smart Smoke } \\
\text { Detectors }\end{array}$ & 2014 & 2013 & New (2021) & 0.0634 & 0.03 & 21 & 1 & $11 \%$ \\
\hline Wireless Earbuds & 2014 & 2014 & New (2021) & 0.0071 & 1.22 & 313 & 7 & $99 \%$ \\
\hline $360^{\circ}$ Cameras & 2015 & 2011 & Extended & 0.0071 & 0.70 & 2 & 9 & $97 \%$ \\
\hline $\begin{array}{l}\text { Connected } \\
\text { Health Devices }\end{array}$ & 2015 & 2010 & Extended & 0.0007 & 0.49 & 423 & 17 & $99 \%$ \\
\hline
\end{tabular}


Table 5 (continued)

\begin{tabular}{lllllllll}
\hline Product & $\begin{array}{l}\text { Data Start } \\
\text { Year }\end{array}$ & $\begin{array}{l}\text { Launch } \\
\text { Year }\end{array}$ & Dataset & $p$ & $q$ & $N$ (million) & $T^{*}$ & $\mathrm{R}^{2}$ \\
\hline $\begin{array}{l}\text { Connected } \\
\text { Switches }\end{array}$ & 2015 & 2012 & Extended & 0.0290 & 0.26 & 44 & 9 & $74 \%$ \\
Dash Cameras & 2015 & 2009 & Extended & 0.0047 & 0.16 & 28 & 24 & $80 \%$ \\
Pet Tech & 2015 & 2011 & Extended & 0.0043 & 0.22 & 322 & 20 & $100 \%$ \\
Smart Speakers & 2015 & 2014 & Extended & 0.0798 & 0.32 & 216 & 5 & $77 \%$ \\
\hline
\end{tabular}

Data Start Year is the year in which the product first appeared in the CTA dataset. It forms the basis for the division of datasets to GLM and the New dataset. The Extended dataset contains six products with seven datapoints only, and thus these products are not included in the saddle analyses.

\section{Web Appendix A}

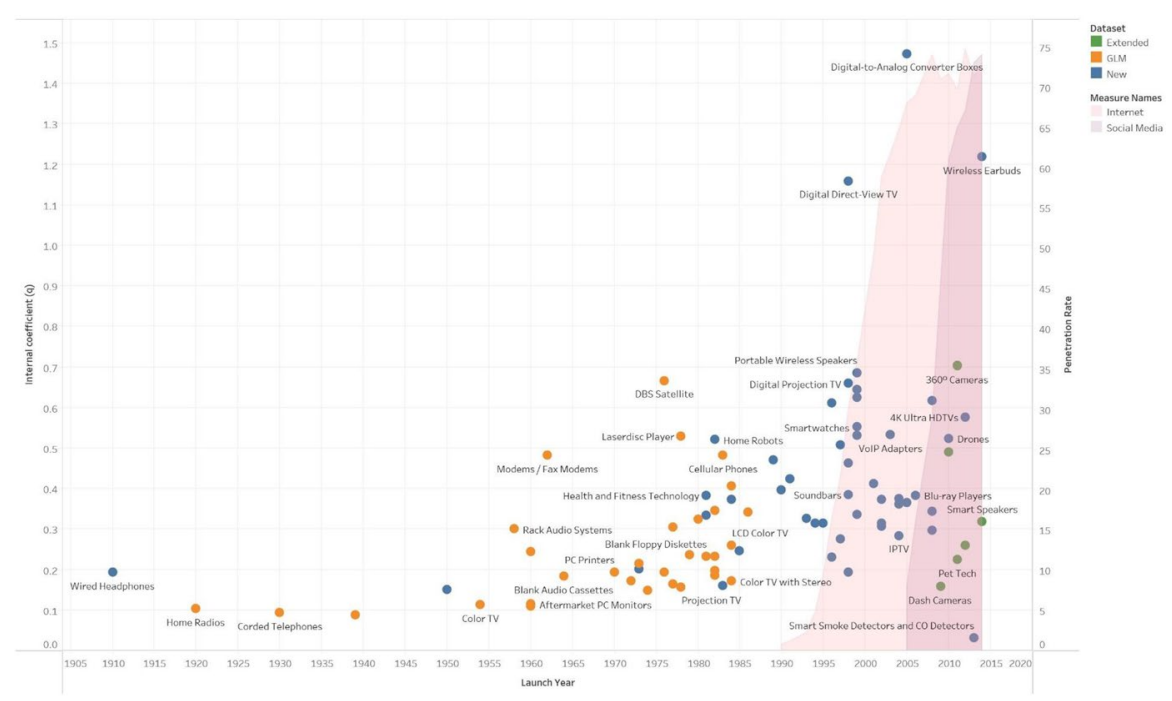

Figure 3 Scatter plot of the internal coefficient $(q)$ over time with an overlay of internet and social media penetration 
Supplementary Information The online version contains supplementary material available at https://doi. org/10.1007/s11002-021-09578-4.

Acknowledgements The authors would like to thank Don Lehmann Marketing Letters Replication Corner Editor, Barak Libai, and Jacob Goldenberg for a number of helpful comments and suggestions.

Open Access This article is licensed under a Creative Commons Attribution 4.0 International License, which permits use, sharing, adaptation, distribution and reproduction in any medium or format, as long as you give appropriate credit to the original author(s) and the source, provide a link to the Creative Commons licence, and indicate if changes were made. The images or other third party material in this article are included in the article's Creative Commons licence, unless indicated otherwise in a credit line to the material. If material is not included in the article's Creative Commons licence and your intended use is not permitted by statutory regulation or exceeds the permitted use, you will need to obtain permission directly from the copyright holder. To view a copy of this licence, visit http://creativecommons.org/licen ses/by/4.0/.

\section{References}

Appel, G., Grewal, L., Hadi, R., \& Stephen, A. T. (2020). The future of social media in marketing. Journal of the Academy of Marketing Science, 48(1), 79-95.

Chandrasekaran, D., \& Tellis, G. J. (2011). Getting a grip on the saddle: chasms or cycles? Journal of Marketing, 75(4), 21-34.

Chu, K. H., Pitts, S. R., Wipfli, H., \& Valente, T. W. (2017). Coding communications across time: documenting changes in interaction patterns across adopter categories. Networking Science, 5(4), 441-460.

Goldenberg, J., Libai, B., \& Muller, E. (2002). Riding the saddle: how cross-market communications can create a major slump in sales. Journal of Marketing, 66(2), 1-16.

Goldenberg, J., Libai, B., Muller, E., \& Peres, R. (2006). Blazing saddles: the early and mainstream markets in the high-tech product life cycle. Israel Economic Review, 4(2), 85-108.

Golder, P. N., \& Tellis, G. J. (1993). Pioneer advantage: marketing logic or marketing legend? Journal of Marketing Research, 30(2), 158-170.

Golder, P. N., \& Tellis, G. J. (2004). Growing, growing, gone: cascades, diffusion, and turning points in the product life cycle. Marketing Science, 23(2), 207-218.

Hauser, J., Tellis, G. J., \& Griffin, A. (2006). Research on innovation: a review and agenda for marketing science. Marketing Science, 25(6), 687-717.

Lehmann, D. R., \& Esteban-Bravo, M. (2006). When giving some away makes sense to jump-start the diffusion process. Marketing Letters, 17(4), 243-254.

Li, H., Jain, S., \& Kannan, P. K. (2019). Optimal design of free samples for digital products and services. Journal of Marketing Research, 56(3), 419-438.

Mahajan, V., Muller, E., \& Srivastava, R. K. (1990). Determination of adopter categories by using innovation diffusion models. Journal of Marketing Research, 27(1), 37-50.

Mclean, R. (2015). Uber Hits 1 Billion Rides. MSNBC, available at: https://money.cnn.com/2015/12/31/ technology/uber-billion-rides/. Accessed 18 Jan 2021.

Muller, E. (2020). Delimiting disruption: why Uber is disruptive, but Airbnb is not. International Journal of Research in Marketing, 37(1), 43-55.

Rogers, E. M. (2003). Diffusion of innovations (B. Wallace, ed.), New York: Free Press.

Sood, A., \& Kumar, V. (2017). Analyzing client profitability across diffusion segments for a continuous innovation. Journal of Marketing Research, 54(6), 932-951.

Srinivasan, V., \& Mason, C. H. (1986). Nonlinear least squares estimation of new product diffusion models. Marketing Science, 5(2), 169-178.

Van den Bulte, C., \& Joshi, Y. V. (2007). New product diffusion with influentials and imitators. Marketing Science, 26(3), 400-421. 
Wilson, P. (2013). A sign past its time - billions of burgers. CBC, available at: https://www.cbc.ca/ news/canada/hamilton/headlines/paul-wilson-a-sign-past-its-time-billions-of-burgers-1.1931665. Accessed 17 Jan 2021.

Zervas, G., Proserpio, D., \& Byers, J. W. (2017). The rise of the sharing economy: estimating the impact of Airbnb on the hotel industry. Journal of Marketing Research, 54(5), 687-705.

Publisher's note Springer Nature remains neutral with regard to jurisdictional claims in published maps and institutional affiliations. 